Article

\title{
Initial Corrosion Behavior of 12Cr1MoV Steel in Thiosulfate-Containing Sodium Aluminate Solution
}

\author{
Jingjiu Yuan ${ }^{1,2}$, Chaoyi Chen ${ }^{1,2, *}$, Junqi Li ${ }^{1,2}$, Bianli Quan ${ }^{1,2}$, Yuanpei Lan ${ }^{1,2}$, Linzhu Wang ${ }^{1,2}$, \\ Hui Fu ${ }^{1,2}$ and Jiaxuan Gai ${ }^{1,2}$ \\ 1 College of Materials and Metallurgy, Guizhou University, Guiyang 550025, China; yuanjj2019@126.com (J.Y.); \\ jqli@gzu.edu.cn (J.L.); blquan@gzu.edu.cn (B.Q.); yplan@gzu.edu.cn (Y.L.); lzwang@gzu.edu.cn (L.W.); \\ fuh1218@126.com (H.F.); gaijiaxuan0911@163.com (J.G.) \\ 2 Guizhou Province Key Laboratory of Metallurgical Engineering and Process Energy Saving, \\ Guiyang 550025, China \\ * Correspondence: cychen@gzu.edu.cn; Tel.: +86-150-8601-5817
}

Received: 26 August 2020; Accepted: 23 September 2020; Published: 25 September 2020

\begin{abstract}
When alumina is produced by the Bayer process with high-sulfur bauxite, the sulfur would strongly corrode the $12 \mathrm{Cr} 1 \mathrm{MoV}$ steel made heat exchanger. This study investigated the initial corrosion behavior of the $12 \mathrm{Cr} 1 \mathrm{MoV}$ steel exposed to a thiosulfate-containing sodium aluminate (TCSA) solution under the evaporation conditions of alumina production. The obtained corrosion rate equation is $V=6.306 \cdot t \cdot \exp (-0.71)$. As corrosion progressed, with the corrosion product film growing, the corrosion current density declines slowly, and the corrosion resistance of the steel is increased. At 1-3 days, the corrosion product film consisted of $\mathrm{FeO}, \mathrm{Fe}_{2} \mathrm{O}_{3}$, and $\mathrm{FeOOH} . \mathrm{S}_{2} \mathrm{O}_{3}{ }^{2-}$ lead to corrosion in local areas of the steel and pits appeared. $\mathrm{AlO}_{2}{ }^{-}$is transformed into $\mathrm{Al}(\mathrm{OH})_{3}$ and filled in the corrosion pits. At 4 and 5 days, $\mathrm{Fe}_{3} \mathrm{O}_{4}$ is generated in the outermost layer, and $\mathrm{Al}(\mathrm{OH})_{3}$ is shed from the corrosion pits. The corrosion mechanism of $12 \mathrm{Cr} 1 \mathrm{MoV}$ steel in a TCSA solution is proposed based on the experimental results.
\end{abstract}

Keywords: $12 \mathrm{Cr} 1 \mathrm{MoV}$ steel; corrosion; sodium aluminate solution; corrosion time; $\mathrm{S}_{2} \mathrm{O}_{3}{ }^{2-}$

\section{Introduction}

High-sulfur bauxite is used for the industrial production of alumina, where sulfur, in the form of pyrite $\left(\mathrm{FeS}_{2}\right)$, is converted into $\mathrm{S}^{2-}, \mathrm{S}_{2} \mathrm{O}_{3}{ }^{2-}$ and other ions in a sodium aluminate solution [1-3]. The accumulation of sulfur in the solution causes a series of hazards, such as the loss of alkalinity and the reduction of the alumina dissolution rate [4]. During the evaporation of the sodium aluminate solution, the sulfur strongly corrodes the heat exchanger made from $12 \mathrm{Cr} 1 \mathrm{MoV}$ steel [5]. Although some desulfurization methods, such as roasting desulfurization [6] and wet desulfurization [7], can remove most of the sulfur, the sulfur concentration would continue to increase as the number of sodium aluminate solution cycles increasing. Thus, the corrosion behavior of $12 \mathrm{Cr} 1 \mathrm{MoV}$ steel in the sodium aluminate solution has become an important problem to study.

Currently, the mechanism of $12 \mathrm{Cr} 1 \mathrm{MoV}$ steel corrosion, especially in solutions containing thiosulfate $\left(\mathrm{S}_{2} \mathrm{O}_{3}{ }^{2-}\right)$, remains unclear. In the mid-1940s, corrosion failures caused by $\mathrm{S}_{2} \mathrm{O}_{3}{ }^{2-}$ were observed in the paper and pulp industry [8-10]. In areas where the passivation film on the steel surface is broken, $\mathrm{S}_{2} \mathrm{O}_{3}{ }^{2-}$ tends to be reduced to $\mathrm{S}$ by the following reaction:

$$
\mathrm{S}_{2} \mathrm{O}_{3}{ }^{2-}+6 \mathrm{H}^{+}+4 \mathrm{e}^{-}=2 \mathrm{~S}+3 \mathrm{H}_{2} \mathrm{O}
$$

Sulfur hinders the repair of the passivation film because the $\mathrm{S}$ deposited during this reaction stimulating the anode process on the active surface, and it prevents the adsorption of $\mathrm{OH}^{-}$. Due to the 
inhibitory effect of the oxide film, $\mathrm{S}$ can only form on the active surface of the steel. In addition, acidic solutions promote the formation of the S. Some studies [11-13] proposed that the corrosion caused by $\mathrm{S}_{2} \mathrm{O}_{3}{ }^{2-}$ occurs only in the presence of a substance that could attack the passivation film or when the passivation film was damaged due to mechanical stress. In addition, there are a few studies on the corrosion behavior of sulfur in the sodium aluminate solution on steel [14-16]. Xie et al. [14] found that the mechanism of corrosion in $\mathrm{S}^{2-}$-containing sodium aluminate solutions became similar to active dissolution. Through electrochemical corrosion and spray corrosion tests, Fu et al. [15] found that the corrosion degree of Q345 steel increased with the increase of sulfide ion concentration. In a solution containing $\mathrm{S}^{2-}$ and $\mathrm{S}_{2} \mathrm{O}_{3}{ }^{2-}$, an increased $\mathrm{S}_{2} \mathrm{O}_{3}{ }^{2-}$ concentration led to more significant corrosion of the steel, and a good product film protective matrix was formed on its surface, which has been reported by Quan et al. [16]. However, few studies have been carried out on sodium aluminate solutions containing solely $\mathrm{S}_{2} \mathrm{O}_{3}{ }^{2-}$. Therefore, the corrosion behavior of steel in a thiosulfate-containing sodium aluminate (TCSA) solution was studied, which was of great significance to the formulation of anti-corrosion scheme and the production and application of high-sulfur bauxite.

The purpose of this study is to investigate the corrosion behavior of the $12 \mathrm{Cr} 1 \mathrm{MoV}$ steel in a TCSA solution by simulating the evaporation conditions of sodium aluminate during alumina production. The initial corrosion behavior mechanism was revealed in terms of the corrosion rate, characterization and composition of the corrosion products, and electrochemical analysis.

\section{Materials and Methods}

\subsection{Materials and Solution}

$12 \mathrm{Cr} 1 \mathrm{MoV}$ steel was used in this study, and its chemical compositions are shown in Table 1. The samples were machined into $15 \times 10 \times 2 \mathrm{~mm}$ blocks for the corrosion experiments and electrochemical measurements. The working electrode (WE) was connected to a copper wire and mounted in epoxy resin with a $1.5 \mathrm{~cm}^{2}$ area exposed. The specimens were sequentially ground using $\mathrm{SiC}$ paper from 180 to 1500 grit, polished with a $2.5 \mu \mathrm{m}$ diamond powder, rinsed with deionized water and alcohol, and dried in cold air. The TCSA solution contained $255 \mathrm{~g} \cdot \mathrm{L}^{-1} \mathrm{Na}_{2} \mathrm{O}, 110 \mathrm{~g} \cdot \mathrm{L}^{-1}$ dissolved alumina (as $\mathrm{Al}_{2} \mathrm{O}_{3}$ ), and an amount of $\mathrm{Na}_{2} \mathrm{~S}_{2} \mathrm{O}_{3} \cdot 5 \mathrm{H}_{2} \mathrm{O}$ that was equivalent to $5 \mathrm{~g} \cdot \mathrm{L}^{-1} \mathrm{~S}_{2} \mathrm{O}_{3}{ }^{2-}$ $(\mathrm{pH}=14.6)$. The solution was prepared by using analytical-grade reagents and deionized water.

Table 1. Chemical compositions of $12 \mathrm{Cr} 1 \mathrm{MoV}$ steel (wt\%).

\begin{tabular}{ccccccc}
\hline $\mathbf{C}$ & $\mathbf{C r}$ & Mo & V & Si & Mn & Fe \\
\hline 0.14 & 0.98 & 0.22 & 0.18 & 0.23 & 0.61 & Balance \\
\hline
\end{tabular}

\subsection{Corrosion Experiments}

The specimens were placed in $120 \mathrm{~mL}$ of TCSA solution. Corrosion experiments were conducted at $110{ }^{\circ} \mathrm{C}$ for different times $(1,2,3,4$, or 5 days (d)) in an autoclave. Three specimens were used for each experiment. The corrosion products were washed by immersion in a solution $(500 \mathrm{~mL} \mathrm{HCl}+5 \mathrm{~g}$ $\mathrm{C}_{6} \mathrm{H}_{12} \mathrm{~N}_{4}+500 \mathrm{~mL} \mathrm{H}_{2} \mathrm{O}$ ) and the change in weight due to material lost over time was used to calculate the average corrosion rate by Equation (2) [5]:

$$
V_{\text {corr }}=\left(m_{0}-m_{1}\right) / A t
$$

where $V_{\text {corr }}$ is the average corrosion rate $\left(\mathrm{g} \cdot \mathrm{m}^{-2} \cdot \mathrm{d}^{-1}\right) ; m_{0}$ and $m_{1}$ are the initial and final masses of the sample (g), respectively; $A$ is the surface area of sample $\left(\mathrm{m}^{2}\right)$; and $t$ is the corrosion time (d).

\subsection{Analysis of Corrosion Products}

After the corrosion experiments, the morphology and composition of the corrosion products on $12 \mathrm{Cr} 1 \mathrm{MoV}$ steel were analyzed by scanning electron microscopy (SEM, SUPRA 40, Zeiss, Jena, Germany) 
and energy dispersive spectroscopy (EDS, AZtec, Oxford Instruments, Oxon, UK). The components of the corrosion products were analyzed X-ray diffraction (XRD, X'pert Pro MPD, Panalytical, Almelo, The Netherlands) with $\mathrm{CuK} \alpha$ radiation $(0.15406 \mathrm{~nm})$ at $40 \mathrm{kV}$ and $40 \mathrm{~mA}$. The scanning range of $2 \theta$ was set from $10^{\circ}$ to $90^{\circ}$. The software of HighScore Plus (Panalytical, Almelo, The Netherlands) was selected to analyze the data. X-ray photoelectron spectroscopy (XPS) (K-Alpha+ $(h v=1486.6 \mathrm{eV})$, Thermo Fisher Scientific, Waltham, MA, USA) was carried out to further understand the phase composition and structure of the corrosion products. The $\mathrm{C} 1 \mathrm{~s}$ peak at $284.8 \mathrm{eV}$ was used as a reference to adjust the shifted charge and the data was conducted via the commercial software XPSpeak version 4.1.

\subsection{Electrochemical Tests}

Electrochemical tests were performed using a potentiostat (VPS, Bio-Logic Science Instruments, Claix, France) equipped with a three-electrode cell. A platinum wire was used as the counter electrode (CE), and a saturated calomel electrode (SCE) was used as the reference electrode (RE). The SCE needs to work at temperatures less than $60^{\circ} \mathrm{C}$. So, the cell was placed in a water bath to maintain the temperature at $55^{\circ} \mathrm{C}$. The TCSA solution was used as the corrosion medium. Before the electrochemical measurements were performed, the WE was immersed in the TCSA solution to be corroded for different times $(1,2,3,4$, or $5 \mathrm{~d})$ at $95^{\circ} \mathrm{C}$. Due to experimental conditions, the immersion corrosion temperature was set at $95{ }^{\circ} \mathrm{C}$. The tests were repeated three times to guarantee the repeatability. Electrochemical impedance spectroscopy (EIS) measurements were taken at the open-circuit potential in the $100 \mathrm{kHz}-10 \mathrm{mHz}$ frequency range with a perturbing signal of $10 \mathrm{mV}$. The polarization curve was measured by sweeping the potential in the positive direction at $0.5 \mathrm{mV} \cdot \mathrm{s}^{-1}$. The potential ranged from $-1.5 V_{S C E}$ to $1.0 V_{S C E}$. Before each test, the electrode potential was held for at least $30 \mathrm{~min}$ to ensure that the system was stabilized.

\section{Results and Discussion}

\subsection{Corrosion Rate Analysis}

The corrosion rates of $12 \mathrm{Cr} 1 \mathrm{MoV}$ steel with different corrosion times at $110^{\circ} \mathrm{C}$ are shown in Figure 1. With the corrosion time increased, the corrosion rate decline slowly. There is a marked decrease in the corrosion rate between $1 \mathrm{~d}$ and $3 \mathrm{~d}$. At $4 \mathrm{~d}$ and $5 \mathrm{~d}$, the corrosion rate is low. As corrosion products formed on the entire surface, the active corrosion reaction is inhibited, and the corrosion rate decreased [17]. The corrosion rate equation is fitted as follows [5]:

$$
V=6.306 \cdot t \cdot \exp (-0.71)
$$

where $V$ is the corrosion rate $\left(\mathrm{g} \cdot \mathrm{m}^{-2} \cdot \mathrm{d}^{-1}\right)$; $t$ is the corrosion time $(\mathrm{d}) ; 6.306$ is the corrosion coefficient; and -0.71 is the corrosion trend. The $R^{2}$ value is 0.9971 .

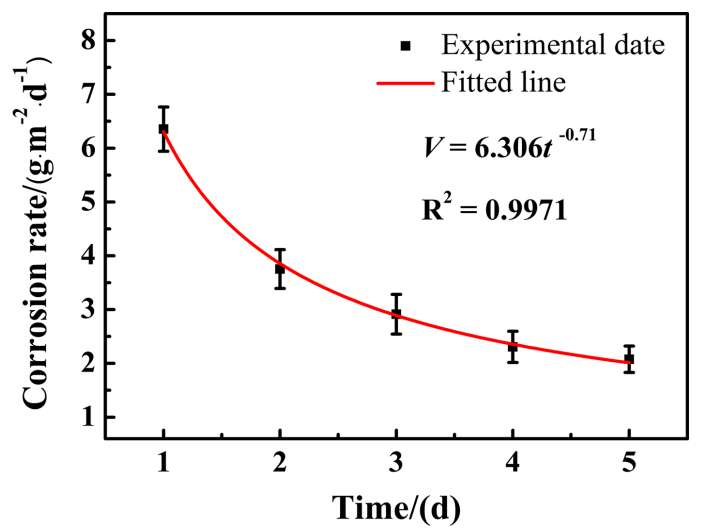

Figure 1. Corrosion rates of $12 \mathrm{Cr} 1 \mathrm{MoV}$ steel for different corrosion times. 


\subsection{SEM-EDS Analysis}

Figure 2 presents the microstructure and EDS point results of the $12 \mathrm{Cr} 1 \mathrm{MoV}$ steel after being corroded for different times in the TCSA solution. After $1 \mathrm{~d}$, many small isolated pits appear on the steel; after $2 \mathrm{~d}$, the pits expand to form corrosion pits, and a white substance accumulates in the corrosion pits. After $3 \mathrm{~d}$, the white substance covers the surface of the corrosion pits. However, after $4 \mathrm{~d}$, particulate corrosion products cover the steel surface, and the white substance in the corrosion pit gradually fall off. This is corresponded to the corrosion rate rapidly decreasing. The EDS analysis of the white substance is carried out in the points marked as A1, A2, and A3 (Figure 2b-d). Those points primarily contain $\mathrm{O}$ and $\mathrm{Al}$, and the atomic ratio of $\mathrm{Al}$ to $\mathrm{O}$ is close to 3 (Figure 2f). Fu et al. [14] found that sodium aluminate was decomposed and the $\mathrm{Al}(\mathrm{OH})_{3}$ formed adhered to the surface of the corrosion product. It can be concluded that the white substance is $\mathrm{Al}(\mathrm{OH})_{3}$. After $5 \mathrm{~d}$, the particulate corrosion products on the steel surface are partially shed. The corrosion rate declines slowly and tends to be stable. This type of particulate corrosion product is very important for decreasing in the corrosion rate.
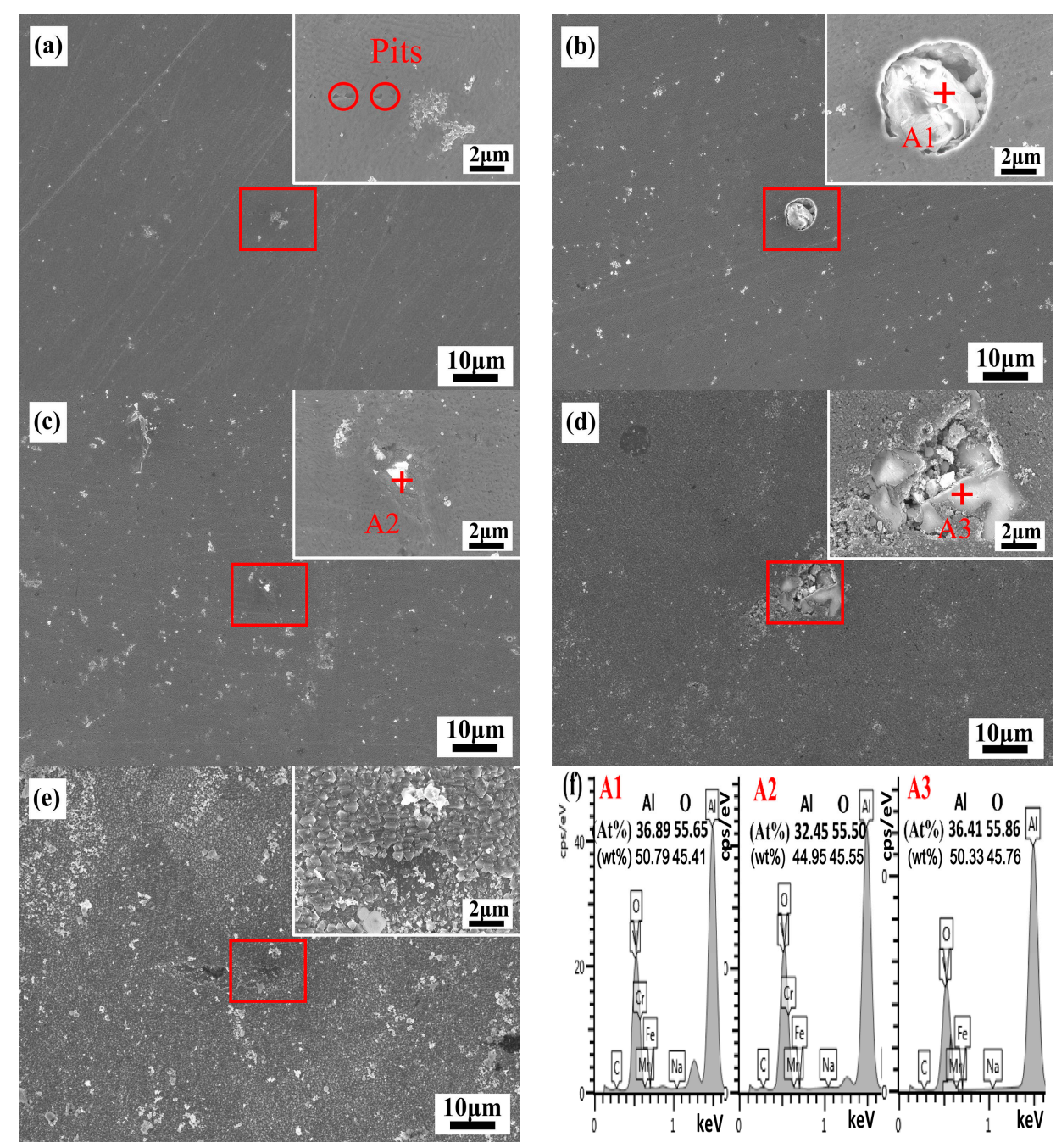

Figure 2. SEM morphologies (a-e) and EDS (f) point measurements of $12 \mathrm{Cr} 1 \mathrm{MoV}$ steel after corroded for (a) 1, (b) 2, (c) 3, (d) 4, and (e) 5 d in the thiosulfate-containing sodium aluminate (TCSA) solution at $110^{\circ} \mathrm{C}$.

Table 2 shows the EDS mapping results of the $12 \mathrm{Cr} 1 \mathrm{MoV}$ steel corroded for different times in the TCSA solution. At 1-3 d, the $\mathrm{O}$ content is relatively low, and the $\mathrm{S}$ content is almost non-existent. 
A small amount of $\mathrm{Al}$ element is present. At this stage, the corrosion products are composed mainly of an oxygen-iron compound. This also reveals that no sulfides are produced on the surface of the steel. In addition, some compounds containing Al formed and decline slowly in size. Between 4 and $5 \mathrm{~d}$, the $\mathrm{O}$ content rapidly increase, and the $\mathrm{Al}$ content declines slowly. This reveals that the corrosion products are mainly composed of iron oxides. In addition, the small amounts of the aluminum compounds which formed earlier in the corrosion process begin to decrease gradually.

Table 2. EDS mapping results of $12 \mathrm{Cr} 1 \mathrm{MoV}$ steel corroded for different times in the TCSA solution (wt $\%$ ).

\begin{tabular}{cccccccc}
\hline Time/d & $\mathbf{O}$ & $\mathbf{S}$ & $\mathbf{C r}$ & $\mathbf{M n}$ & $\mathbf{A l}$ & $\mathbf{N a}$ & $\mathbf{F e}$ \\
\hline 1 & 6.59 & - & 0.62 & 0.28 & 0.15 & 0.32 & Balance \\
2 & 4.26 & - & 0.75 & 0.46 & 0.35 & 0.26 & Balance \\
3 & 6.37 & - & 0.74 & 0.42 & 1.15 & 0.01 & Balance \\
4 & 27.22 & 0.15 & 1.06 & 0.77 & 1.06 & 0.43 & Balance \\
5 & 26.80 & 0.18 & 0.83 & 0.62 & 0.37 & 0.25 & Balance \\
\hline
\end{tabular}

\subsection{Analysis of the Phase and Chemical Composition of the Corrosion Products}

The XRD patterns of the $12 \mathrm{Cr} 1 \mathrm{MoV}$ steel after being corroded for different times at $110{ }^{\circ} \mathrm{C}$ in the TCSA solution are shown in Figure 3. At 1, 2, and 3 d, only the matrix iron (Fe) peaks are found in XRD patterns, which indicate that the corrosion is not significant, and the product film is thin at this stage. After being corroded for 4 and $5 \mathrm{~d}$, the corrosion product is composed of $\mathrm{Fe}_{3} \mathrm{O}_{4}$, and the peak intensities increase gradually, which indicate that the crystallinity of $\mathrm{Fe}_{3} \mathrm{O}_{4}$ is stronger.

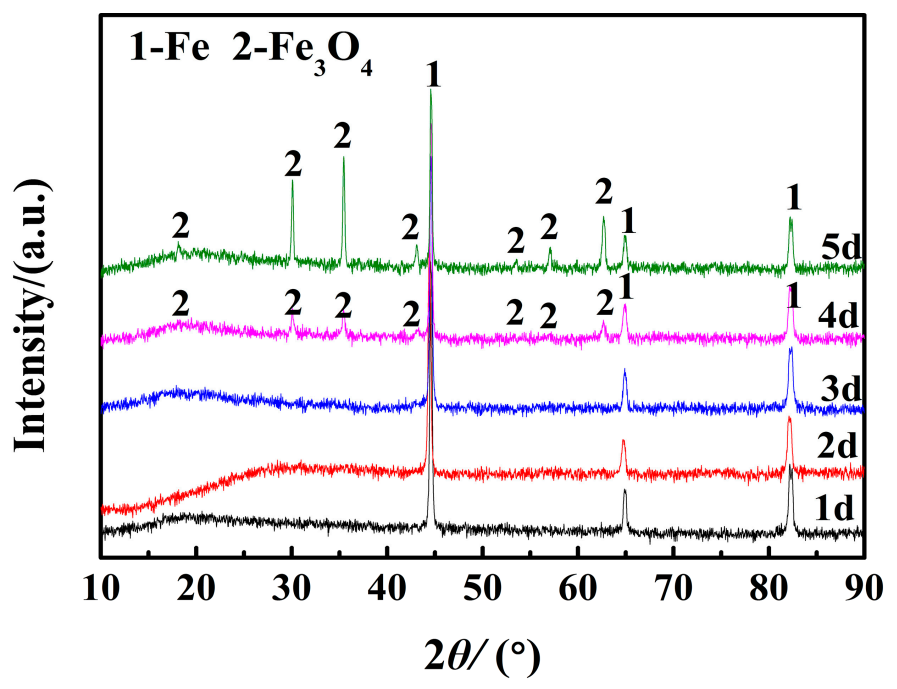

Figure 3. XRD patterns of $12 \mathrm{Cr} 1 \mathrm{MoV}$ steel corroded for different times at $110^{\circ} \mathrm{C}$ in the TCSA solution.

To further understand the corrosion products, XPS characterizations were used to survey the elemental states of the $\mathrm{Fe}, \mathrm{O}$, and $\mathrm{Al}$ species. Figure 4 shows the XPS results of the $12 \mathrm{Cr} 1 \mathrm{MoV}$ steel corroded in the TCSA solution for 1, 3, and $5 \mathrm{~d}$ for the Fe2p, O1s, and A12p spectra. As shown in Figure $4 \mathrm{a}$, the $\mathrm{Fe} 2 \mathrm{p}$ spectra can be separated into several constituent peaks representing the $\mathrm{FeO}$ $(708.6 \pm 0.3 \mathrm{eV}), \mathrm{Fe}_{2} \mathrm{O}_{3}(710.1 \pm 0.3 \mathrm{eV})$, and $\mathrm{FeOOH}(711.9 \pm 0.3 \mathrm{eV})$ [18-20]. After $5 \mathrm{~d}$, the $\mathrm{Fe}_{2} \mathrm{O}_{3} / \mathrm{FeO}$ intensity ratio of 1.5 is markedly above that corresponding to $\mathrm{Fe}_{3} \mathrm{O}_{4}$ and $\mathrm{Fe}_{2} \mathrm{O}_{3}$ (ratio of 1). Figure $4 \mathrm{~b}$ shows that three peaks for O1s are observed in the spectra at $529.6 \pm 0.3,531.4 \pm 0.3$, and $532.4 \pm 0.3 \mathrm{eV}$, which corresponded to $\mathrm{O}^{2-}, \mathrm{FeOOH}$, and $\mathrm{Al}(\mathrm{OH})_{3}$ [21-23], respectively. It was noted that the $\mathrm{OH}^{-}$ peaks are very weak after only $1 \mathrm{~d}$ of corrosion. This indicates that the dominant $\mathrm{O}$ species in the corrosion products changes from $\mathrm{O}^{2-}$ to $\mathrm{OH}^{-}$as the corrosion time increases. The $\mathrm{Al} 2 \mathrm{p}$ band consists of one peak at $74.2 \pm 0.2 \mathrm{eV}$, which corresponds to $\mathrm{Al}(\mathrm{OH})_{3}$ [22], as shown in Figure 4c. Combining 
the XRD and EDS results, the corrosion products of $12 \mathrm{Cr} 1 \mathrm{MoV}$ steel corroded for $1 \mathrm{~d}$ were mainly composed of $\mathrm{Fe}_{2} \mathrm{O}_{3}, \mathrm{FeOOH}$, and $\mathrm{FeO}$, with a smaller amount of $\mathrm{Al}(\mathrm{OH})_{3}$. After $3 \mathrm{~d}$, a measurable amount of $\mathrm{FeOOH}$ form on the steel surface. Xia [24] also found that $\mathrm{OH}^{-}$formed later than $\mathrm{O}^{2-}$ and was enriched in the outermost passive film layer. After $5 \mathrm{~d}$, the corrosion products are mainly composed of $\mathrm{Fe}_{3} \mathrm{O}_{4}$.
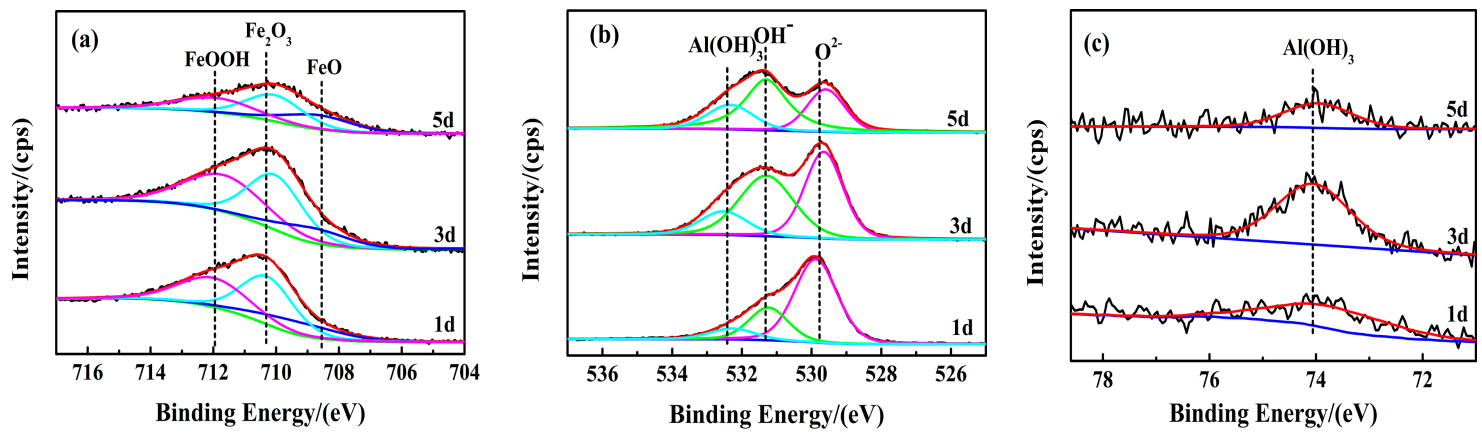

Figure 4. XPS spectra of $12 \mathrm{Cr} 1 \mathrm{MoV}$ steel corroded in the TCSA solution for 1, 3, and 5 d: (a) Fe2p, (b) O1s, and (c) Al2p.

\subsection{Analysis of the Polarization Curves}

Figure 5 illustrates the polarization curves of $12 \mathrm{Cr} 1 \mathrm{MoV}$ steel corroded for different time in the TCSA solution at $55^{\circ} \mathrm{C}$. The anodic polarization curves could be divided into four regions: active, active-passive transition, passive, and transpassive regions. The corrosion potential was around $-1.2 \mathrm{~V}$ vs. SCE.

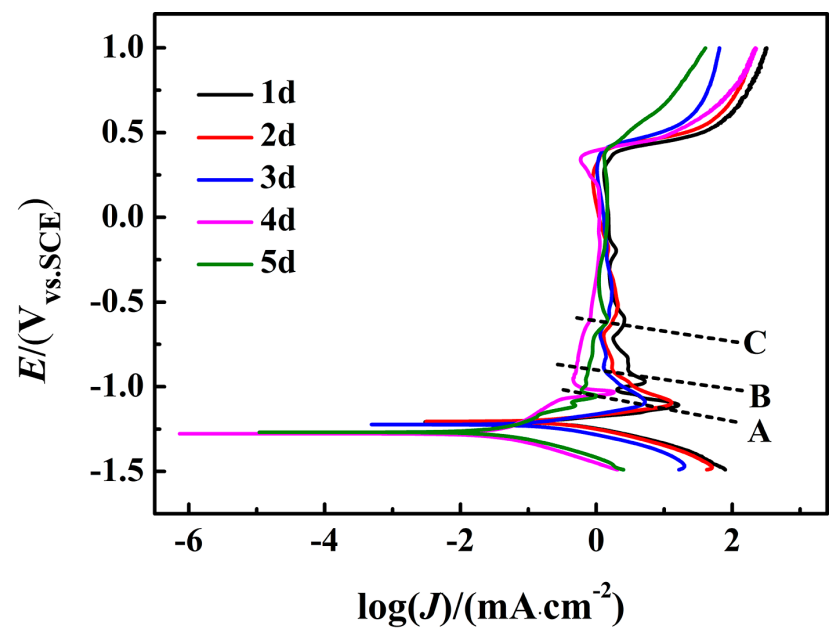

Figure 5. Polarization curves of $12 \mathrm{Cr} 1 \mathrm{MoV}$ steel corroded in the TCSA solution for different times $(1 \mathrm{~d}, 2 \mathrm{~d}, 3 \mathrm{~d}, 4 \mathrm{~d}$, or $5 \mathrm{~d})$ at $55^{\circ} \mathrm{C}$.

According to previous studies $[5,14,16]$, the following reactions occur. The peak $\mathrm{A}$ at $-1.1 V_{S C E}$ is attributed to the Fe matrix actively dissolving to form $\mathrm{Fe}(\mathrm{OH})_{3}{ }^{-}$through Equation (4).

$$
\mathrm{Fe}+3 \mathrm{H}_{2} \mathrm{O} \rightarrow \mathrm{Fe}(\mathrm{OH})_{3}^{-}+3 \mathrm{H}^{+}+2 \mathrm{e}^{-}
$$

The peak $\mathrm{B}$ at $-0.8 \mathrm{~V}$ versus SCE may be associated with the formation of $\mathrm{Fe}_{3} \mathrm{O}_{4}$ through Equation (5). However, as the corrosion time increases, peak B gradually disappears, implying that the corrosion product film has a significant effect on the passivation behavior. In addition, $\mathrm{S}_{2} \mathrm{O}_{3}{ }^{2-}$ may participate in the reaction through Equations (6) and (7). 


$$
\begin{gathered}
3 \mathrm{Fe}(\mathrm{OH})_{3}{ }^{-}+\mathrm{H}^{+} \rightarrow \mathrm{Fe}_{3} \mathrm{O}_{4}+5 \mathrm{H}_{2} \mathrm{O}+2 \mathrm{e}^{-} \\
\mathrm{S}_{2} \mathrm{O}_{3}{ }^{2-}+8 \mathrm{H}^{+}+8 \mathrm{e}^{-} \rightarrow 2 \mathrm{HS}^{-}+3 \mathrm{H}_{2} \mathrm{O} \\
\mathrm{Fe}_{3} \mathrm{O}_{4}+3 \mathrm{HS}^{-}+5 \mathrm{H}^{+}+2 \mathrm{e}^{-} \rightarrow 3 \mathrm{FeS}+4 \mathrm{H}_{2} \mathrm{O}
\end{gathered}
$$

The peak $\mathrm{C}$ at $-0.6 \mathrm{~V}$ versus SCE may be associated with the formation $\mathrm{FeOOH}$ or $\mathrm{Fe}_{3} \mathrm{O}_{4}$, as shown in Equations (8) and (9).

$$
\begin{aligned}
\mathrm{Fe}_{3} \mathrm{O}_{4}+2 \mathrm{H}_{2} \mathrm{O} & \rightarrow 3 \mathrm{FeOOH}+\mathrm{H}^{+}+\mathrm{e}^{-} \\
2 \mathrm{Fe}_{3} \mathrm{O}_{4}+2 \mathrm{OH}^{-} & \rightarrow 3 \mathrm{Fe}_{2} \mathrm{O}_{3}+\mathrm{H}_{2} \mathrm{O}+2 \mathrm{e}^{-}
\end{aligned}
$$

Table 3 shows $E_{\text {corr }}$ and the corrosion current density $\left(J_{\text {corr }}\right)$, and the Tafel slope values, which are obtained from Figure 5 using EC-Lab V11.20 software (Bio-Logic Science Instruments, Claix, France). The value of $E_{\text {corr }}$ shifts toward negative potentials as the corrosion time increased. In contrast, the $J_{\text {corr }}$ value decreases from 265.6 to $41.192 \mu \mathrm{A} \cdot \mathrm{cm}^{-2}$ when the corrosion time increases from 1 to $5 \mathrm{~d}$. The $J_{\text {corr }}$ value decreases rapidly from 132.344 to $49.328 \mu \mathrm{A} \cdot \mathrm{cm}^{-2}$ at $4 \mathrm{~d}$, implying that the formation of the corrosion product film affects the corrosion rate of the steel.

Table 3. Polarization results of $12 \mathrm{Cr} 1 \mathrm{MoV}$ steel.

\begin{tabular}{ccccc}
\hline Time $(\mathbf{d})$ & $\boldsymbol{E}_{\text {corr }}(\mathbf{m V})$ & $J_{\text {corr }}\left(\boldsymbol{\mu} \mathbf{A} \cdot \mathbf{c m}^{-\mathbf{2}}\right)$ & $\boldsymbol{\beta}_{\boldsymbol{a}}\left(\mathbf{m V} \cdot \mathbf{d e c}^{-\mathbf{1}}\right)$ & $\boldsymbol{\beta}_{\boldsymbol{c}}\left(\mathbf{m V} \cdot \mathbf{d e c}^{\mathbf{- 1})}\right.$ \\
\hline 1 & -1208.46 & 265.6 & 55.8 & 83.8 \\
2 & -1205.59 & 226.392 & 63.2 & 86.3 \\
3 & -1222.86 & 132.344 & 77.7 & 77.4 \\
4 & -1267.89 & 49.328 & 252.7 & 19.4 \\
5 & -1271.53 & 41.192 & 308.8 & 141.8 \\
\hline
\end{tabular}

\subsection{EIS Analysis}

The EIS spectra of $12 \mathrm{Cr} 1 \mathrm{MoV}$ steel after being corroded for different times in the TCSA solution at $55^{\circ} \mathrm{C}$ are shown in Figure 6. The capacitive reactance arc in the high frequency region corresponds to the passive film, whereas the low frequency region corresponds to the charge transfer process at the film/solution interface [25]. While the absolute value of the maximum phase angle is smaller, the corrosion product film on the steel surface is rougher. At $1 \mathrm{~d}$, the steel has the smoothest surface. According to Nyquist plots, Bode plots, and the relevant literature analysis, two time constants (state variables) should be considered, one of which reflects the nature of the surface layer and the other reflects charge transfer on the surface of the electrode [14].
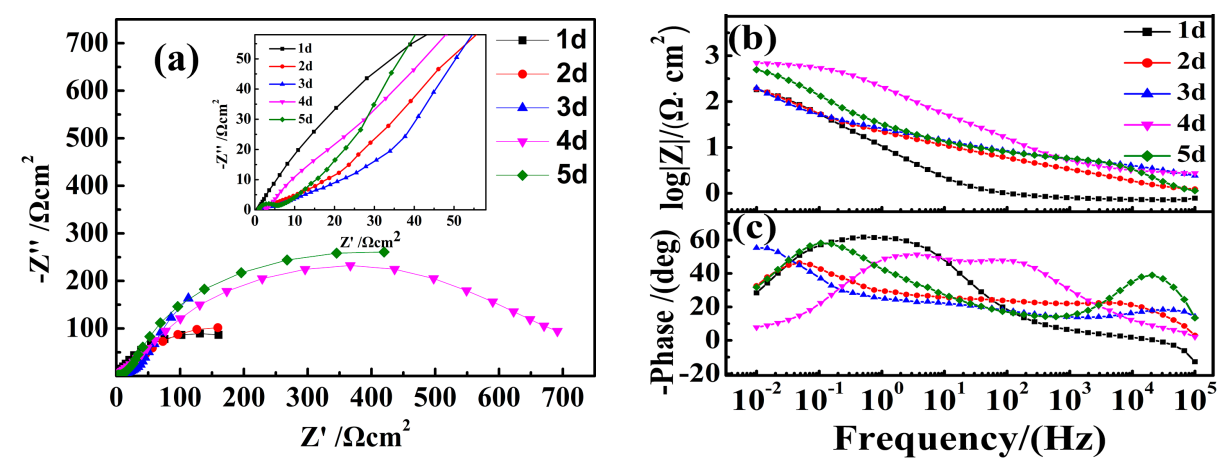

Figure 6. Electrochemical impedance spectroscopy (EIS) spectra results of $12 \mathrm{Cr} 1 \mathrm{MoV}$ steel corroded for different times in the TCSA solution at $55^{\circ} \mathrm{C}$ : (a) Nyquisy piot, (b) Bode plot (log|Z| vs. frequency), (c) Bode plot (phase angle vs. frequency). 
The EIS spectra were fitted with the electrochemical equivalent circuit using EC-Lab V11.20 software. The equivalent circuit is shown in Figure 7 and impedance parameters obtained on the $12 \mathrm{Cr} 1 \mathrm{MoV}$ steel electrode after corroded different time in TCSA solution is shown Table 4. The equivalent circuit diagram $R_{s}+Q_{f} /\left(R_{f}+Q_{d l} / R_{c t}\right)$ has an electric double-layer capacitance with two time constants [14,16]. $R_{S}$ stands for the solution resistance, $R_{c t}$ and $R_{f}$ represent the charge-transfer resistances and corrosion product film, respectively, and $Q_{f}$ and $Q_{d l}$ represent the product layer capacitance and constant-potential capacitance, respectively. The value of $R_{f}$ is relatively high from 4 to $5 \mathrm{~d}$, which may be associated with the growth of the corrosion product film. In particular, the $R_{c t}$ values of the samples corroded for 4 and $5 \mathrm{~d}$ are higher than those of the samples corroded 1-3 $d$, suggesting that the charge-transfer phenomena is more difficult. Based on the above electrochemical results, it can be clarified that as the corrosion time increased, the corrosion product film gradually formed, and the corrosion resistance of the steel gradually improved $[25,26]$. The enhanced corrosion resistance should be related to the changes in the composition of the product film [27].

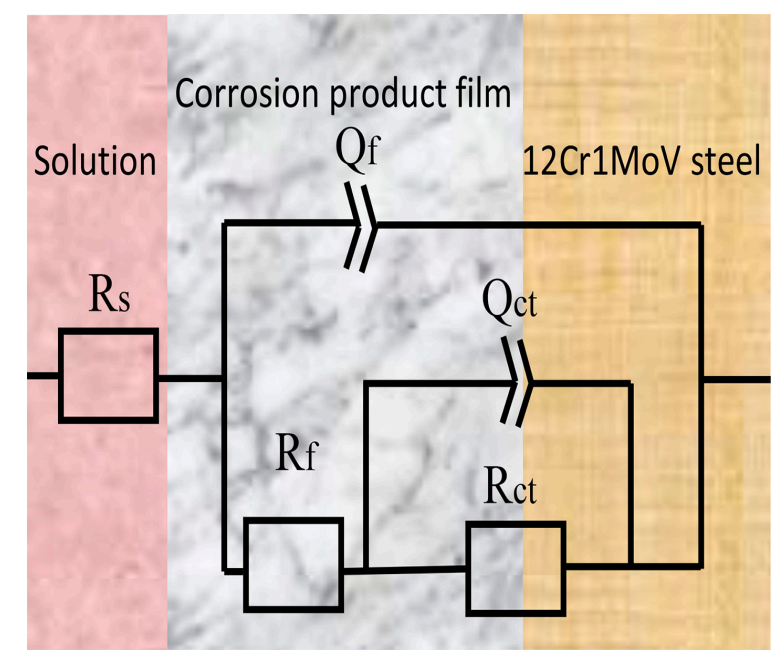

Figure 7. The equivalent electric circuit used to fit the impedance data.

Table 4. Impedance parameters obtained on the $12 \mathrm{Cr} 1 \mathrm{MoV}$ steel electrode after corroded different time in TCSA solution.

\begin{tabular}{|c|c|c|c|c|c|c|c|c|}
\hline $\begin{array}{l}\text { Time } \\
\text { (d) }\end{array}$ & $\begin{array}{c}R_{s} \\
\left(\Omega \cdot \mathrm{cm}^{2}\right)\end{array}$ & $\begin{array}{c}R_{c t} \\
\left(\Omega \cdot \mathrm{cm}^{2}\right)\end{array}$ & 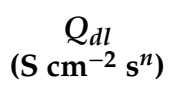 & $n_{\mathrm{dl}}$ & $\begin{array}{c}R_{f} \\
\left(\Omega \cdot \mathrm{cm}^{2}\right)\end{array}$ & $\begin{array}{c}Q_{f} \\
\left(\mathrm{~S} \mathrm{~cm}^{-2} \mathrm{~s}^{n}\right)\end{array}$ & $n_{f}$ & $\begin{array}{c}X^{2} \\
\left(10^{-4}\right)\end{array}$ \\
\hline 1 & 0.8 & 154 & 0.001 & 0.74 & 122 & 0.024 & 0.74 & 7.54 \\
\hline 2 & 1.0 & 179 & 0.031 & 0.86 & 229 & 0.048 & 0.84 & 6.81 \\
\hline 3 & 1.2 & 491 & 0.026 & 0.74 & 550 & 0.082 & 0.93 & 7.96 \\
\hline 4 & 0.7 & 593 & 0.003 & 0.97 & 690 & 0.002 & 0.59 & 6.35 \\
\hline 5 & 0.8 & 643 & 0.0001 & 0.69 & 1281 & 0.010 & 0.66 & 5.26 \\
\hline
\end{tabular}

\subsection{Analysis of the Cross-Section of the Corrosion Product Film}

Figure 8 shows the morphologies, elemental mapping, and line scan of the cross-section of the corrosion product film on the $12 \mathrm{Cr} 1 \mathrm{MoV}$ steel after corroding for $5 \mathrm{~d}$ in the TCSA solution. A uniform and continuous product film is observed. The $\mathrm{O}$ and Fe contents are enriched in the film. Small amounts of $\mathrm{Al}$ are also presented in the corrosion product layer. A line scan and element mapping of the cross section reveal that the growth of the film is driven by diffusion. From Figure $8 b$, the strength of the Fe peaks gradually decreases from surface to steel matrix as well as the strength of the Al peaks. The amount of $\mathrm{O}$ gradually increased and then slightly decreased. According to the distribution of $\mathrm{O}$, there are two layers in the film: the inner and outer layer. The XRD analysis confirms the presence of $\mathrm{Fe}_{3} \mathrm{O}_{4}$ on the steel surface (Figure 3). From the results of the SEM-EDS and XPS analysis (Figure 2, 
Table 2, and Figure 4), the inner layer is mainly composed of $\mathrm{FeO}, \mathrm{Fe}_{2} \mathrm{O}_{3}, \mathrm{FeOOH}$, and a smaller amount of $\mathrm{Al}(\mathrm{OH})_{3}$. The outer layer is mainly consisted of $\mathrm{Fe}_{3} \mathrm{O}_{4}$.

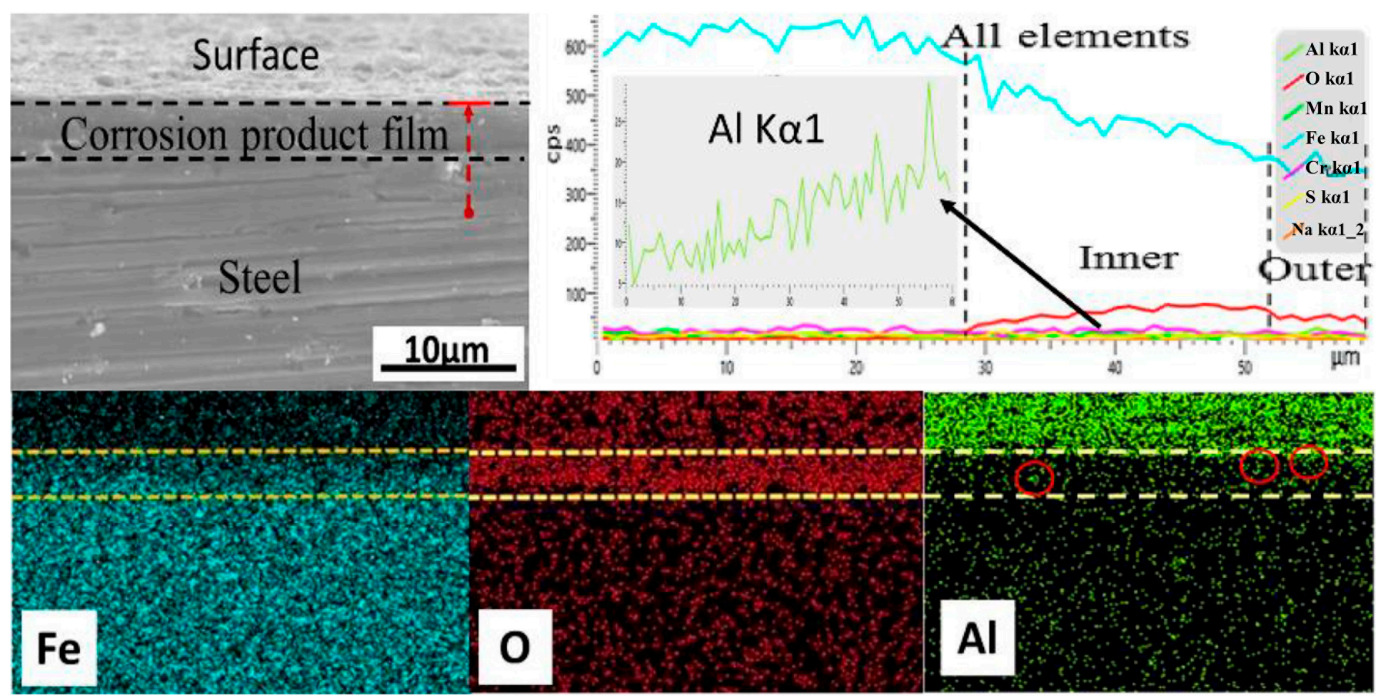

Figure 8. Morphologies, elemental mapping, and line scan of the cross-section of the corrosion product film on the $12 \mathrm{Cr} 1 \mathrm{MoV}$ steel after $5 \mathrm{~d}$ of corrosion in the TCSA solution.

\subsection{Corrosion Mechanism}

Based on the above results and relevant previous studies [28-31], a schematic of the corrosion product film on the $12 \mathrm{Cr} 1 \mathrm{MoV}$ steel after corrosion in the TCSA solution is proposed, as is shown in Figure 9.

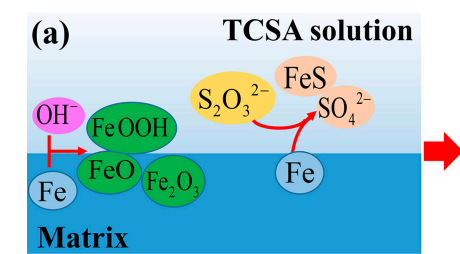

(d) (b)

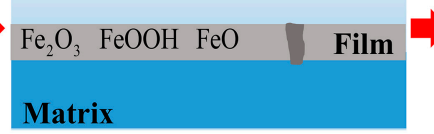

TCSA solution
TCSA solution

(e) (c)

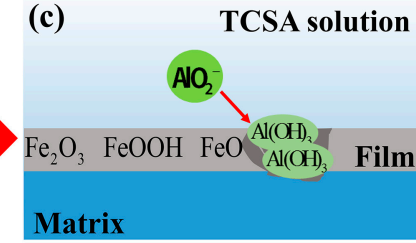

TCSA solution

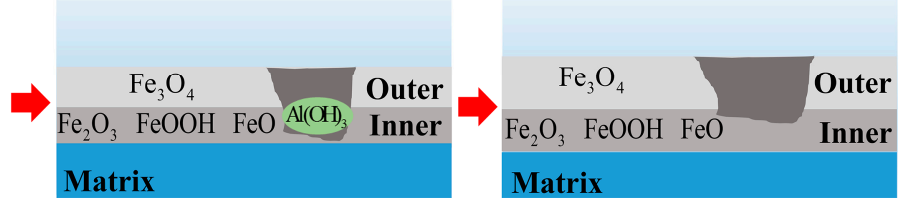

Figure 9. Schematic (a-e) of the corrosion product film formed on the $12 \mathrm{Cr} 1 \mathrm{MoV}$ steel surface when immersed in the TCSA solution.

In the early stage (1-3 d), there is a competitive adsorption of $\mathrm{OH}^{-}, \mathrm{AlO}_{2}{ }^{-}$, and $\mathrm{S}_{2} \mathrm{O}_{3}{ }^{2-}$ in the solution. $\mathrm{OH}^{-}$is adsorbed onto the surface of the steel to form $\mathrm{FeO}, \mathrm{Fe}_{2} \mathrm{O}_{3}$, and $\mathrm{FeOOH}$ easier than other ions in the early stage (Figure $9 a, b)$. Some studies $[15,16]$ have reported that these corrosion products exist after the steel being corroded in sodium aluminate solution. $\mathrm{S}_{2} \mathrm{O}_{3}{ }^{2-}$ is adsorbed in the steel and forms $\mathrm{SO}_{4}{ }^{2-}, \mathrm{FeS}$, and pits on the surface of the steel (Figure $9 \mathrm{a}, \mathrm{b}$ ). However, $\mathrm{SO}_{4}{ }^{2-}$ and $\mathrm{FeS}$ were dissolved in the solution. There is a wide consensus that $\mathrm{S}_{2} \mathrm{O}_{3}{ }^{2-}$ and its decomposition products did not occur in the film $[8,32]$. As corrosion progresses, pits continue to form corrosion pits. Interestingly, $\mathrm{AlO}_{2}{ }^{-}$can be converted into $\mathrm{Al}(\mathrm{OH})_{3}$ in the corrosion pits (Figure 9c) [33]. The crystallization precipitation of $\mathrm{Al}(\mathrm{OH})_{3}$ was related to $\mathrm{pH}$ value. It may be concluded that a large amount of $\mathrm{Al}(\mathrm{OH})_{3}$ 
are formed with lower $\mathrm{pH}$ value in the corrosion pits [34]. Meanwhile, the corrosion current density and the corrosion rate decrease gradually.

In the later stages ( 4 and $5 \mathrm{~d}$ ), $\mathrm{Fe}_{3} \mathrm{O}_{4}$ is generated in the outermost film, and $\mathrm{Al}(\mathrm{OH})_{3}$ sheds from the corrosion pits (Figure 9d). There are defects in the area near the corrosion product film on the steel surface (Figure 9e). The formation of the product film has an important influence on the corrosion process: the corrosion current density decreases, and the corrosion resistance of the steel gradually improved. The film has a strong protection capability.

\section{Conclusions}

The initial corrosion behavior of the $12 \mathrm{Cr} 1 \mathrm{MoV}$ steel in a TCSA solution was explored in this paper. As the corrosion time increased, the corrosion rates declined slowly. The corrosion rate equation is $V=6.306 \cdot t \cdot \exp (-0.71)$. According to the electrochemical results, the corrosion current density gradually decreases, and the corrosion resistance of steel is increased. The corrosion mechanism of the $12 \mathrm{Cr} 1 \mathrm{MoV}$ steel in a TCSA solution is proposed. In the early stages $(1-3 \mathrm{~d})$, the corrosion product film consisted of $\mathrm{FeO}, \mathrm{Fe}_{2} \mathrm{O}_{3}$, and $\mathrm{FeOOH}$. $\mathrm{S}_{2} \mathrm{O}_{3}{ }^{2-}$ caused by corrosion in local areas of steel and pits appeared. $\mathrm{AlO}_{2}{ }^{-}$is transformed into $\mathrm{Al}(\mathrm{OH})_{3}$ and fills in the corrosion pits. In the later stages (4 and $5 \mathrm{~d}), \mathrm{Fe}_{3} \mathrm{O}_{4}$ is generated in the outmost layer, and $\mathrm{Al}(\mathrm{OH})_{3}$ is shed from the corrosion pits.

Author Contributions: J.Y., C.C., J.L., B.Q., Y.L., L.W., H.F. and J.G. conceived of and designed the experiments; J.Y., H.F. and J.G. carried out the experiments; J.Y. analyzed the data; C.C., J.L., B.Q., Y.L. and L.W. contributed reagents, materials, and analysis tools; and J.Y. wrote the paper. All authors have read and agreed to the published version of the manuscript.

Funding: This work was supported by the Projects (U1812402, 51574095, 52074096, 51664005, 51564003, 51804088, and 51804086) supported by the National Natural Science Foundation of China; Project by Guizhou Education Department (KY (2015) 334, YJSCXXJH (2019) 002) and Project (Platform Talent (2017) 5626, (2017) 5788, and Talent Team Giant (2015) 4005) supported by Guizhou Natural Science Found; Young talent introduction program of Guizhou University (702688203301).

Acknowledgments: The authors would like to acknowledge the National Natural Science Foundation of China, Guizhou Education Department, Guizhou Natural Science Found, and Guizhou University.

Conflicts of Interest: The authors declare no conflict of interest.

\section{References}

1. Li, X.B.; Wang, Y.L.; Zhou, Q.S.; Qi, T.G.; Liu, G.H.; Peng, Z.H.; Wang, H.Y. Reaction Behaviors of Iron and Hematite in Sodium Aluminate Solution at Elevated Temperature. Hydrometallurgy 2018, 175, $257-265$. [CrossRef]

2. Li, X.B.; Li, C.Y.; Peng, Z.H.; Liu, G.H.; Zhou, Q.S.; Qi, T.G. Interaction of Sulfur with Iron Compounds in Sodium Aluminate Solutions. Trans. Nonferr. Metal. Soc. 2015, 25, 608-614. [CrossRef]

3. Liu, Z.W.; Yan, H.W.; Ma, W.H.; Xie, K.Q.; Xu, B.Q.; Zheng, L.C. Digestion behavior and removal of sulfur in high-sulfur bauxite during bayer process. Miner. Eng. 2020, 149, 106237. [CrossRef]

4. Li, X.B.; Niu, F.; Tan, J.; Liu, G.H.; Qi, T.G.; Peng, Z.H.; Zhou, Q.S. Removal of S2- Ion From Sodium Aluminate Solutions with Sodium Ferrite. Trans. Nonferr. Metal. Soc. 2016, 26, 1419-1424. [CrossRef]

5. Yuan, J.J.; Chen, C.; Li, J.; Quan, B.; Wang, L.; Lan, Y.; Du, X.; Fu, H. Growth of Corrosion Product Film on $12 \mathrm{Cr} 1 \mathrm{MoV}$ Steel in Sulfur-Containing Sodium Aluminate Solution. Mater. Express 2019, 9, $914-922$. [CrossRef]

6. Lou, Z.N.; Xiong, Y.; Feng, X.D.; Shan, W.J.; Zhai, Y.C. Study on the Roasting and Leaching Behavior of High-Sulfur Bauxite Using Ammonium Bisulfate. Hydrometallurgy 2016, 165, 306-311. [CrossRef]

7. Zhou, X.J.; Yin, J.G.; Chen, Y.L.; Xia, W.T.; Xiang, X.Y.; Yuan, X.L. Simultaneous Removal of Sulfur and Iron by the Seed Precipitation of Digestion Solution for High-Sulfur Bauxite. Hydrometallurgy 2018, 181, 7-15. [CrossRef]

8. Cabrini, M.; Lorenzi, S.; Pastore, T. Effects of Thiosulphates and Sulphite Ions on Steel Corrosion. Corros. Sci. 2018, 135, 158-166. [CrossRef] 
9. Gomez-Duran, M.; Macdonald, D.D. Stress Corrosion Cracking of Sensitized Type 304 Stainless Steel in Thiosulfate Solution: I. Fate of the Coupling Current. Corros. Sci. 2003, 45, 1455-1471. [CrossRef]

10. Wensley, D.A.; Charlton, R.S. Corrosion Studies in Kraft White Liquor Potentiostatic Polarization of Mild Steel in Caustic Solutions Containing Sulfur Species. Corrosion 1980, 36, 385-389. [CrossRef]

11. Park, J.O.; Verhoff, M.; Alkire, R. Microscopic Behavior of Single Corrosion Pits: The Effect of Thiosulfate on Corrosion of Stainless Steel in NaCl. Electrochim. Acta 1997, 42, 3281-3291. [CrossRef]

12. Kuo, H.S.; Chang, H.; Tsaia, W.T. The Corrosion Behavior of AISI 209 Stainless Steel in Thiosulfate Ion Containing Saturated Ammonium Chloride Solution. Corros. Sci. 1999, 41, 669-684. [CrossRef]

13. Laitinen, T. Localized Corrosion of Stainless Steel in Chloride, Sulfate and Thiosulfate Containing Environments. Corros. Sci. 2000, 42, 421-441. [CrossRef]

14. Xie, Q.L.; Chen, W.M. Corrosion Behavior of 16Mn Low Alloy Steel in Sulfide-Containing Bayer Solutions. Corros. Sci. 2014, 86, 252-260. [CrossRef]

15. Fu, H.; Chen, C.; Li, J.; Lan, Y.; Wang, L.; Yuan, J. Influence of Na2S On the Corrosion Behavior of Q345 Steel in Sodium Aluminate Solution. Mater. Res. Express 2019, 6, 1-11. [CrossRef]

16. Quan, B.L.; Li, J.Q.; Chen, C.Y. Synergy Corrosion Effect of Thiosulfate and Sulfide on Q235 Steel in Sodium Aluminate Solution. Mater. Res. Express 2019, 6, 025607.

17. Zhang, D.Z.; Gao, X.H.; Du, L.X.; Wang, H.X.; Liu, Z.G.; Yang, N.N.; Misra, R.D.K. Corrosion Behavior of High-Strength Steel for Flexible Riser Exposed to CO2-Saturated Saline Solution and CO2-Saturated Vapor Environments. Acta Metall. Sin-Engl. 2019, 32, 607-617. [CrossRef]

18. Cui, Z.Y.; Wang, L.W.; Ni, H.T.; Hao, W.K.; Man, C.; Chen, S.S.; Wang, X.; Liu, Z.Y.; Li, X.G. Influence of Temperature on the Electrochemical and Passivation Behavior of 2507 Super Duplex Stainless Steel in Simulated Desulfurized Flue Gas Condensates. Corros. Sci. 2017, 118, 31-48. [CrossRef]

19. Ghods, P.; Isgor, O.B.; Brown, J.R.; Bensebaa, F.; Kingston, D. XPS Depth Profiling Study on the Passive Oxide Film of Carbon Steel in Saturated Calcium Hydroxide Solution and the Effect of Chloride on the Film Properties. Appl. Surf. Sci. 2011, 257, 4669-4677. [CrossRef]

20. Lv, M.Y.; Du, M.; Li, X.; Yue, Y.Y.; Chen, X.C. Mechanism of Microbiologically Influenced Corrosion of X65 Steel in Seawater Containing Sulfate-Reducing Bacteria and Iron-Oxidizing Bacteria. J. Mater. Res. Technol. 2019, 8, 4066-4078. [CrossRef]

21. Baranwal, P.K.; Rajaraman, P.V. Kinetics of Carbon Steel Dissolution in Ammonium Chloride Solution Containing Sodium Thiosulfate. Int. J. Chem. Kinet. 2019, 51, 497-510. [CrossRef]

22. Kim, M.; Yoo, H.; Choi, J. Non-Nickel-Based Sealing of Anodic Porous Aluminum Oxide in NaAlO2. Surf. Coat. Tech. 2017, 310, 106-112. [CrossRef]

23. Krawiec, H.; Stypuła, B.; Stoch, J.; Mikołajczyk, M. Corrosion Behaviour and Structure of the Surface Layer Formed on Austempered Ductile Iron in Concentrated Sulphuric Acid. Corros. Sci. 2006, 48, 595-607. [CrossRef]

24. Xia, D.H.; Sun, Y.F.; Shen, C.; Chen, X.Y.; Fan, H.Q.; Luo, J.L. A Mechanistic Study on Sulfur-Induced Passivity Degradation on Alloy 800 in Simulated Alkaline Crevice Chemistries at Temperatures Ranging From $21^{\circ} \mathrm{C}$ to $300{ }^{\circ}$ C. Corros. Sci. 2015, 100, 504-516. [CrossRef]

25. Ye, Y.W.; Liu, Z.Y.; Liu, W.; Zhang, D.W.; Zhao, H.C.; Wang, L.P.; Li, X.G. Superhydrophobic Oligoaniline-Containing Electroactive Silica Coating as Pre-Process Coating for Corrosion Protection of Carbon Steel. Chem. Eng. J. 2018, 348, 940-951. [CrossRef]

26. Trdan, U.; Grum, J. Evaluation of Corrosion Resistance of AA6082-T651 Aluminium Alloy After Laser Shock Peening by Means of Cyclic Polarisation and ElS Methods. Corros. Sci. 2012, 59, 324-333. [CrossRef]

27. Wang, Z.; Zhou, Z.; Zhang, L.; Hu, J.; Zhang, Z.; Lu, M. Effect of pH on the Electrochemical Behaviour and Passive Film Composition of 316L Stainless Steel. Acta Metall. Sin-Engl. 2019, 32, 585-598. [CrossRef]

28. Hou, Q.; Liu, Z.Y.; Li, C.T.; Li, X.G. The Mechanism of Stress Corrosion Cracking of Alloy 690TT in a Caustic Solution Containing Lead. Corros. Sci. 2017, 128, 154-163. [CrossRef]

29. Liu, C.; Revilla, R.I.; Zhang, D.; Liu, Z.Y.; Lutz, A.; Zhang, F.; Zhao, T.L.; Ma, H.C.; Li, X.G.; Terryn, H. Role of Al2O3 Inclusions on the Localized Corrosion of Q460NH Weathering Steel in Marine Environment. Corros. Sci. 2018, 138, 96-104. [CrossRef]

30. Gu, T.Y.; Jia, R.; Unsal, T.; Xu, D.K. Toward a Better Understanding of Microbiologically Influenced Corrosion Caused by Sulfate Reducing Bacteria. J. Mater. Res. Technol. 2019, 35, 631-636. [CrossRef] 
31. Hwang, E.H.; Park, J.S.; Seong, H.G.; Kim, S.J. Analysis on surface film formed on high-strength carbon steels in acidic phosphate solution and its relationship with localized corrosion in a $3.5 \% \mathrm{NaCl}$ solution. J. Mater. Res. Technol. 2019, 8, 1419-1426. [CrossRef]

32. Duret-Thual, C.; Costa, D.; Yang, W.P.; Marcus, P. The role of thiosulfates in the pitting corrosion of Fe-17Cr alloys in neutral chloride solution: Electrochemical and XPS study. Corros. Sci. 1997, 39, 913-933. [CrossRef]

33. Sipos, $\mathrm{P}$. The structure of $\mathrm{Al}(\mathrm{III})$ in strongly alkaline aluminate solutions-A review. J. Mol. Liq. 2009, 146, 1-14. [CrossRef]

34. Skoufadis, C.; Panias, D.; Paspaliaris, I. Kinetics of boehmite precipitation from supersaturated sodium aluminate solutions. Hydrometallurgy 2003, 68, 57-68. [CrossRef]

(C) 2020 by the authors. Licensee MDPI, Basel, Switzerland. This article is an open access article distributed under the terms and conditions of the Creative Commons Attribution (CC BY) license (http://creativecommons.org/licenses/by/4.0/). 